\title{
Blasts 20 Percent or More of Peripheral Blood White Cells
}

National Cancer Institute

\section{Source}

National Cancer Institute. Blasts 20 Percent or More of Peripheral Blood White Cells. NCI

Thesaurus. Code C36213.

A semi-quantitative microscopic finding indicating that 20 percent or more of the nucleated cells in a peripheral leukocyte sample are immature mononuclear cells. 